\title{
Progressive multifocal leukoencephalopathy and promyelocytic leukemia nuclear bodies: a review of clinical, neuropathological, and virological aspects of $\mathrm{JC}$ virus-induced demyelinating disease
}

\author{
Yukiko Shishido-Hara
}

Received: 1 March 2010/Revised: 11 April 2010/Accepted: 2 May 2010/Published online: 13 May 2010

(C) The Author(s) 2010. This article is published with open access at Springerlink.com

\begin{abstract}
Progressive multifocal leukoencephalopathy is a fatal viral-induced demyelinating disease that was once rare but has become more prevalent today. Over the past decades, much has been learned about the disease from molecular study of the etiological agent of the disease, JC virus. Recently, promyelocytic leukemia nuclear bodies (PML-NBs), punctuate structures for important nuclear functions in eukaryotic cells, were identified as an intranuclear target of JC virus infection. Neuropathologically, JC virus-infected glial cells display diffuse amphophilic viral inclusions by hematoxylin-eosin staining (full inclusions), a diagnostic hallmark of this disease. Recent results using immunohistochemistry, however, revealed the presence of punctate viral inclusions preferentially located along the inner nuclear periphery (dot-shaped inclusions). Dot-shaped inclusions reflect the accumulation of viral progeny at PML-NBs, which may be disrupted after viral replication. Structural changes to PML-NBs have been reported for a variety of human diseases, including cancers and neurodegenerative disorders. Thus, PML-NBs may provide clues to the further pathogenesis of JC virusinduced demyelinating disease. Here, we review what we have learned since the disease entity establishment, including a look at recent progress in understanding the relationship between JC virus, etiology and PML-NBs.
\end{abstract}

Y. Shishido-Hara $(\bowtie)$

Department of Pathology,

Kyorin University School of Medicine,

6-20-2 Shinkawa, Mitaka, Tokyo 181-8611, Japan

e-mail: shishido-hara@y6.dion.ne.jp

Y. Shishido-Hara

Department of Neurology,

Tokyo Metropolitan Institute for Neuroscience, Tokyo, Japan
Keywords Progressive multifocal leukoencephalopathy · JC virus - Promyelocytic leukemia nuclear body (PML-NB) · Full inclusions · Dot-shaped inclusions

\section{Progressive multifocal leukoencephalopathy}

History

Progressive multifocal leukoencephalopathy is a distinct neurologic entity established in 1958 [5]. Two cases of chronic lymphatic leukemia and one case of Hodgkin's lymphoma were described as having similar clinical outcomes and sharing a characteristic neuropathology among postmortem brains. Uniquely, a mixture of small and larger demyelinating lesions was disseminated in the white matter and to a lesser degree, also in the gray matter. The small demyelinating lesions appeared to merge to form larger ones, an arrangement that was distinct from other demyelinating diseases known at that time. The fusion of multifocal demyelinating lesions was regarded as a progressive process and thus, the disease was named progressive multifocal leukoencephalopathy (Fig. 1a).

The diagnostic hallmark of progressive multifocal leukoencephalopathy is the presence of oligodendrocytes with enlarged nuclei containing intranuclear amphophilic inclusions. The presence of abnormally bizarre astrocytes has been also described. A link to viral infection was suggested [19] and two independent groups subsequently revealed the presence of polyomalike virions in round or filamentous forms by electron microscopy $[121,150]$. Isolation of the virus was difficult but primary human fetal glia cells were eventually identified as the first cell culture system that could support viral propagation. Human polyomavirus isolated 

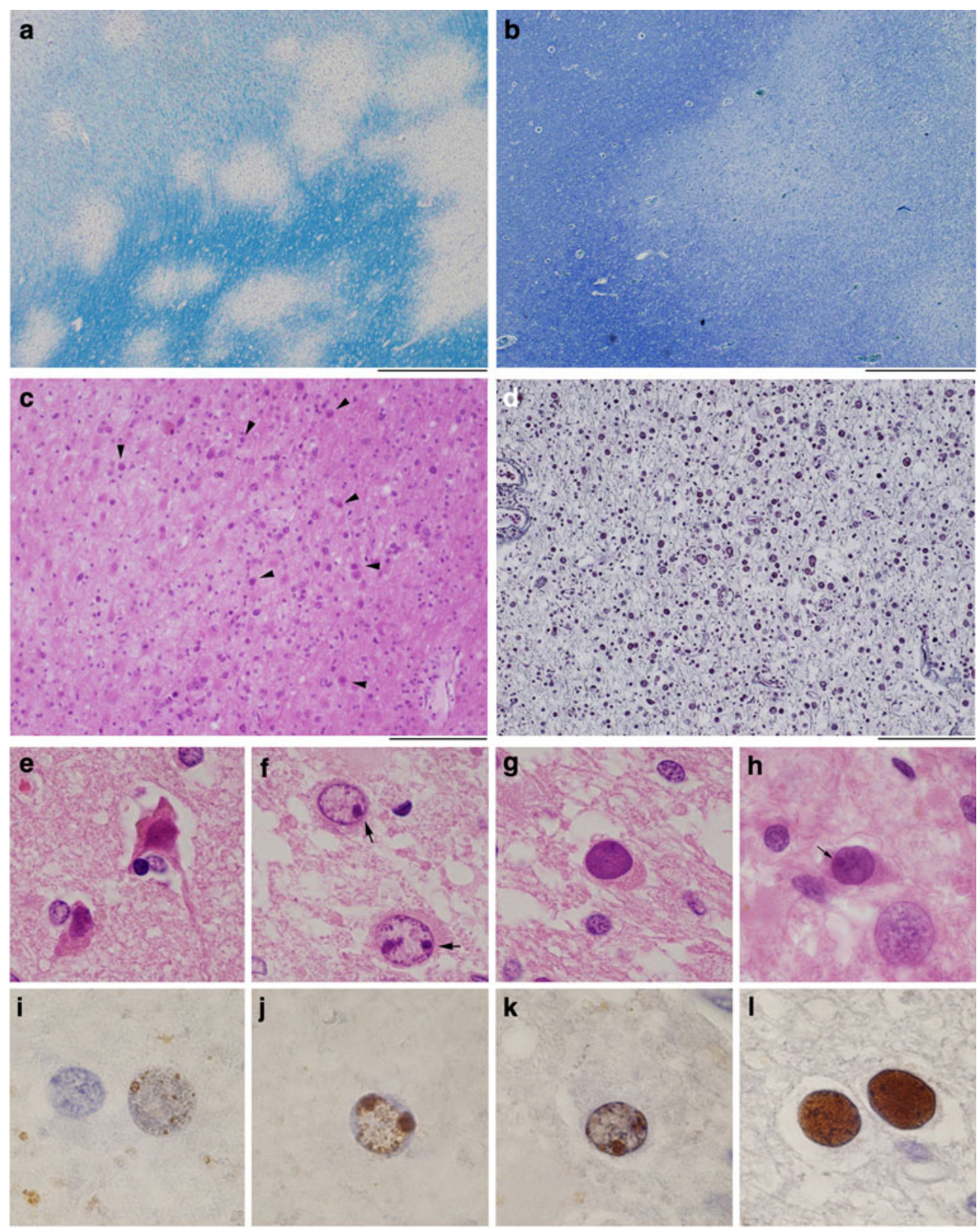

Fig. 1 Neuropathology of progressive multifocal leukoencephalopathy. a Characteristic demyelinating patterns, in which small welldemarcated lesions fuse to form larger lesions [Kluver-Barrera (KB) staining, bar $1.0 \mathrm{~mm}$ ]. b Broad myelin pallor in the white matter (KB staining, bar $1.0 \mathrm{~mm}$ ). c The same section shown in a. Glial cells harboring amphophilic inclusions in the enlarged nuclei (arrowheads) usually seen at the periphery of well-demarcated demyelinating lesions (HE staining, bar $100 \mu \mathrm{m}$ ). d The same section as in $\mathbf{b}$. Glial cells with enlarged nuclei broadly scattered in the myelin pallor (Bodian staining, bar $100 \mu \mathrm{m}$ ). e Small and condensed nuclei of oligodendroglia surrounding cortex neurons. f Glial cells, potentially JC virus-infected oligodendroglias, display enlarged but clear nuclei

from autopsied brain tissue was named JC virus after the patient, Mr. John Cunningham [98]. Progressive multifocal leukoencephalopathy was rare in those days,

without amphophilic inclusions. Dot-shaped structures (arrows) are detected and resemble dot-shaped JC viral inclusions shown in $\mathbf{j}$ and $\mathbf{k}$. g, h Typical cells with intranuclear JC viral inclusions seen in the myelin pallor (g) and at the periphery of well-demarcated demyelination (h) (e-h HE staining, bars $20 \mu \mathrm{m})$. i Immunohistochemistry (IHC) to detect the promyelocytic leukemia (PML) protein. Punctate PML distribution indicating the presence of PML-NBs. $\mathbf{j}, \mathbf{k}$ Viral genomic DNA and capsid proteins VP2/VP3 are detected in punctate patterns (dot-shaped inclusions) by in situ hybridization (j) and IHC (k), respectively. I JC viral capsid proteins, by IHC, are detected throughout the nucleoplasm (full inclusions) (i-l bars $20 \mu \mathrm{m})$

and regarded as a "slow virus infection" of the central nervous system, similar to scrapie, Kuru, and CreutzfeldtJakob disease. 
Clinical aspects observed over the past three decades

Progressive multifocal leukoencephalopathy develops in patients with impaired immunity. The number of reported cases of this previously rare disease has significantly increased since the 1980s due to the pandemic of acquired immunodeficiency syndrome (AIDS). In the south of Florida in the United States, for example, there was a 12fold increase in the frequency of diagnosis in 1990-1994 when compared with 1980-1984 [8]. Introduction of highly active antiretroviral therapy (HAART), initiated in France in 1996, has significantly decreased the morbidity and mortality of AIDS [56]; however, progressive multifocal leukoencephalopathy remains a major AIDS complication resulting in death [52]. Paradoxically, some patients develop a deterioration associated with HAART treatment known as immune reconstitution inflammatory syndrome (IRIS). IRIS can result from reconstitution of the immune system to recognize pathogens/antigens, and can be accompanied by toxoplasmosis, cryptococcosis, and tuberculosis, as well as progressive multifocal leukoencephalopathy $[21,51]$.

In non-AIDS patients, advancements in therapy of underlying diseases and the increasing use of immunomodulatory drugs have markedly changed the clinical background. Among cases associated with lymphoproliferative disorders, Hodgkin's disease was the most frequently reported underlying disease from 1958 to 1989; in contrast, from 1990 to 2004, more reports linked the disease to B cell chronic lymphocytic leukemia and non-Hodgkin's lymphomas [45]. This may be in part because for the latter cases, an increasing number of patients undergo high-dose chemotherapy with hematopoietic stem cell transplantation [48, 67] or treatment with purine analogs such as fludarabine widely used since 1997 [45]. Transplant recipients of solid organs, including kidneys, livers, hearts, or lungs, can also develop demyelination, likely due to immunosuppressive treatments used to prevent graft rejection [120]. The disease can also develop in persons with rheumatic diseases related or unrelated to immunosuppressive drug treatment; indeed, systemic lupus erythematosus is one of the most common underlying diseases [15, 17, 87, 95]. In 2005, development of progressive multifocal leukoencephalopathy was reported with the use of natalizumab, a monoclonal antibody that blocks inflammatory cell entry into the brain and is used for multiple sclerosis and Crohn's disease [70, 79, 135, 148]. Children with congenital immunodeficiency disorders [2] and the elderly (in association with age-related immunosuppression) are also at risk. Thus, progressive multifocal leukoencephalopathy is now relatively common and can develop in association with a large number of different diseases, treatments, and conditions that lead to immunodeficiency.
A diagnosis of progressive multifocal leukoencephalopathy can be indicated by radiological imaging, but detection of JC virus is essential for a definitive diagnosis. JC viral DNA can be detected in the cerebrospinal fluid by polymerase chain reaction (PCR), but negative results do not completely rule out the possibility. For example, PCR results may be negative for HAART-treated AIDS patients, due to clearance of the viral DNA associated with improved immune responses $[16,46]$. Therefore, pathological examination of a biopsy or autopsy sample may be required for a final diagnosis. The clinical prognosis for progressive multifocal leukoencephalopathy is usually poor, with most cases resulting in death within 6 months, although prolonged survival has sometimes been observed $[7,8]$.

\section{Neuropathology}

Neuropathology of progressive multifocal leukoencephalopathy now shows histological diversity, likely associated with the expanded clinical spectrum of underlying diseases. As described earlier, the originally identified neuropathology was a typical arrangement of multiple well-demarcated demyelinating lesions, preferentially seen in the cerebral subcortical white matter [5] (Fig. 1a). However, for some recent cases, apparent cortical demyelination has been reported [11, 86, 127, 140]. The frontal lobes and parietooccipital regions are most commonly affected, but demyelination may be also observed in deep gray structures, the cerebellum, the brainstem, and even in the spinal cord $[9,61,62,115]$.

The degree of histologically detected demyelination and of inflammation is also variable. Some cases display myelin pallor (Fig. 1b), whereas others show marked degeneration associated with axonal damage and the appearance of numerous foamy macrophages harboring phagocytolytic lipids or myelin debris. Such lesions are regarded as "burnt out," and are often observed in cases associated with AIDS [52, 76]. A broad distribution of burnt out lesions may imply prolonged survival concurrent with advanced treatment [52]. The inflammatory response is usually poor; however, in cases of IRIS, severe inflammation may be present, including marked intraparenchymal and perivascular infiltration by macrophages and $\mathrm{T}$ lymphocytes [51, 85, 136].

The etiology of progressive multifocal leukoencephalopathy is JC virus lytic infection leading to the destruction of myelin sheaths. Therefore, detection of glial cells harboring JC virus inclusions is essential for pathological diagnosis. The characteristic cells are usually seen at the periphery of the demyelinating lesions, if the lesions are well demarcated (Fig. 1c). In contrast, if myelin pallor is broadly dispersed, the affected cells also tend to be 
scattered in a relatively broad area (Fig. 1d). The viral inclusions appear as amphophilic material dispersed throughout the nucleoplasm (full inclusions), by hematoxylin-eosin (HE) staining. However, the presence of numerous cells is also noted, which have a clearer nucleoplasm and marginated chromatin but lacking amphophilic material, despite nuclear enlargement (Fig. 1e-h). By immunohistochemistry, some of these cells display a distinct punctate distribution of promyelocytic leukemia (PML) protein, indicating the appearance of promyelocytic leukemia nuclear bodies (PML-NBs; note that for clarity, "PML" refers herein only to promyelocytic leukemia or PML protein, and not to the disease progressive multifocal leukoencephalopathy) (Fig. 1i). Both the JC viral DNA genome and viral capsid proteins show punctate signals by in situ hybridization and immunohistochemistry, respectively (dot-shaped inclusions) (Fig. 1j, k). Because PML protein and JC viral capsid proteins co-localize [117, 118] (Fig. 7), PML-NBs are likely the sites of JC viral replication. Dot-shaped inclusions are indicative of an earlier stage of viral infection, prior to the stage at which full inclusions would be observed (Fig. 1j-1).

By electron microscopy, JC virions are round or filamentous structures, approximately $35-40 \mathrm{~nm}$ in size. Although the intranuclear distributions of viruses are variable, many cells contain more viruses at the periphery than in center of the nucleus. Occasionally, round virions display a perfect alignment pattern, called crystalloid arrays (Fig. 2). This alignment pattern indicates that viral spread

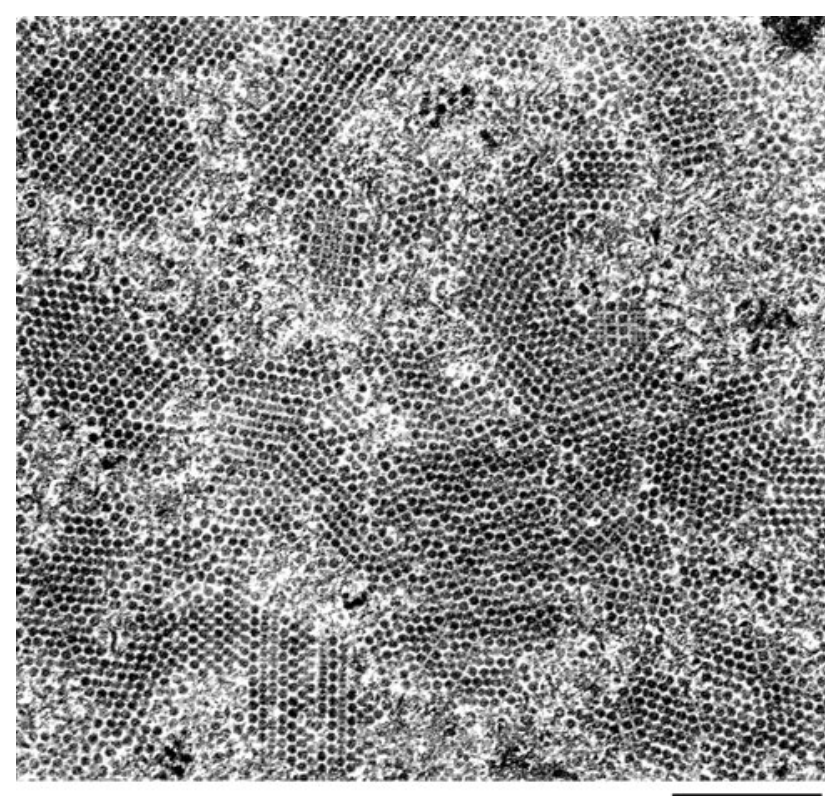

Fig. 2 Electron micrograph of JC virions. JC virions, uniform in both size and shape display perfect alignment patterns called crystalloid arrays $($ Bar $1 \mu \mathrm{m})$. Courtesy of Drs. Shigeki Takeda and Hitoshi Takahashi is associated with specific intranuclear structures, rather than being the result of viruses freely floating in the nucleoplasm. In 1980, Mazlo and Tariska [84] investigated the first phase of viral replication using electron microscopy and reported that viral progeny always appear in the vicinity of the inner nuclear membrane after nuclear enlargement of infected oligodendrocytes. Today, we better understand the development of intranuclear viral inclusions at a molecular level; nevertheless, even 30 years later these new findings are consistent with earlier results based on extensive ultrastructural studies.

\section{The JC virus biology and molecular pathogenesis}

The human polyomavirus JC genome

JC virus has a circular double-stranded DNA genome. The complete sequence was first determined for the Mad-1 strain $(5,130 \mathrm{bp})$ [41]. The first Japanese strain, Tokyo-1 (5,128 bp) was isolated [90], and we determined its complete sequence [116]. JC virus shares approximately $70 \%$ DNA sequence similarity with SV40 and BK virus, and displays a similar tripartite genome organization with early and late coding regions and a regulatory region. The early coding region encodes multifunctional regulatory proteins, large $\mathrm{T}$ antigen and its splicing variants $\left(\mathrm{t}, \mathrm{T}^{\prime}{ }_{135}, \mathrm{~T}^{\prime}{ }_{136}\right.$, and $\mathrm{T}^{\prime}{ }_{165}$ ) [134]. The late region encodes three capsid proteins, VP1, VP2, and VP3, and a small regulatory protein called agnoprotein.

The JC viral regulatory sequence is located between the early and late coding regions, and the promoter-enhancer elements function bidirectionally. The regulatory sequence displays marked diversity, but the sequences can be roughly divided into two groups, "archetype" and "neurotropic type". Viruses isolated from the urine of healthy individuals have consistently been found to contain a characteristic regulatory sequence known as the archetype, which is composed of five segments: 25-, 23-, 55-, 66-, 18bp sequences (Fig. 3). In contrast, viruses isolated from demyelinating brains display divergent sequences designated as the "neurotropic type" (also referred to as the "PML-type" where "PML" means progressive multifocal leukoencephalopathy). The neurotropic type regulatory sequences appear to have arisen from the archetype via deletion and duplication. For example, in the Mad-1 sequence, the 23- and 66-bp segments are deleted, and the 25-, 55-, and 18-bp segments are duplicated, resulting in 98-bp tandem repeats. In the Tokyo-1 sequence, the 66-bp portion is largely deleted, most 55 - and 18-bp segments are duplicated, with a unique 17-bp sequence insertion [83]. Sequence rearrangement from the archetype to the neurotropic type may increase restricted tissue tropism or 


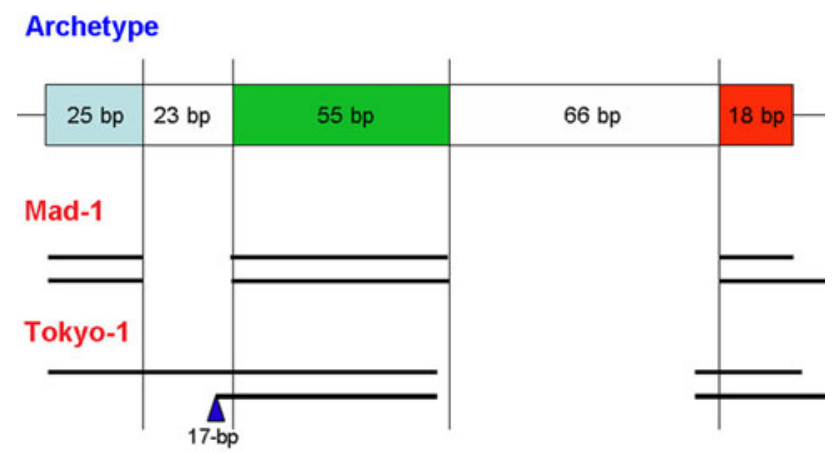

Fig. 3 JC viral regulatory sequences. The viral regulatory sequences are divergent and divided into two groups, the "archetype" and "neurotropic type." The archetype sequence consists of five subsequences, 25-, 23-, 55-, 66-, and 18-bp. The sequence of neurotropic types, such as Mad-1 and Tokyo-1, may be derived from the archetypal sequence via deletion and duplication. For details, refer to Yogo et al. [147]

virulence, thus affecting the overall of pathogenic potential of the virus [22]. However, it is also argued that sequence rearrangement does not change the JC virus biology [124]. The so-called "archetype hypothesis" will be described further below.

The archetype hypothesis

Early interest focused on the idea of "slow virus infection" and the question was frequently raised, how does JC virus persist asymptomatically but in some cases, cause opportunistic demyelinating disease? JC virus is ubiquitous in human populations and approximately $50-80 \%$ of adults present antibodies against the virus [72, 97]. Although seroprevalence continues to increase until the seventh decade of life, most individuals are thought to already have asymptomatic infections by early childhood. Primary infections may occur via respiratory inhalation [109, 113] or through consumption of contaminated food or beverages [12-14]. The viruses are presumably latent or persistent in lymphoid organs such as the spleen or tonsils, as well as bone marrow, and circulate in association with peripheral lymphocytes, monocytes, or cell-free plasma [32, 33, 43, $57,88,133]$. A small amount of virus seems to replicate in the kidney and the virus is occasionally excreted in the urine. Circulating viruses may reach the brain and if host immunity is compromised, the virus can cause progressive multifocal leukoencephalopathy.

In 1990, in what is arguably one of the most important and interesting studies in the field, the presence of the socalled archetypal viruses was advocated [147]. Archetypal viruses are frequently excreted in the urine of healthy individuals [69, 146, 147] and detected in urban sewage [14]. Thus, it seems to be the archetype that circulates in the human population. It has been proposed that subsequent to a primary infection, the archetype remains quiescent in the kidneys or other organs with occasional excretion to the urine. Some time later, the virus may transform to the neurotropic type via sequence rearrangement (in particular, deletion and duplication; see above). Neurotropic type viruses acquire neurovirulence and thus can cause progressive multifocal leukoencephalopathy (Fig. 4a).

Subsequent to the promotion of the archetype idea, how and where the viruses transform from the archetype to the neurotropic type became a subject of debate. If the virus is transmitted via respiratory inhalation, then it would stand to reason that the archetype would be detected in tonsilar tissues, an initial site of infection. In one report, however, viral sequences from such samples were identified as mostly of the neurotropic type [88], although archetypal sequences were detected in another study [63]. JC virus may be transmitted by consumption of contaminated food or beverages [12-14] and consistent with this, JC viral sequences are frequently detectable in the human gastrointestinal (GI) tract [77, 106, 107]. However, according to one study, viral sequences detected in the GI tract were identified as belonging to the Mad-1-like neurotropic type [77]. JC virus may also circulate in the body in association with peripheral blood lymphocytes (PBLs), where sequence arrangement may occur. One study reports that the viruses in PBLs were mostly of the neurotropic type [31], and the presence of both archetype and neurotropic types was reported in another study [6]. Bone marrow has also been suggested as the site of transformation, as neurotropic type virus has been detected there as well [130]. Making the story yet more confusing, the presence of JC viral DNA has repeatedly been detected in postmortem brain tissue taken from patients who died from non-neurologic diseases [29, 36, 99, 141]. Unexpectedly, these viruses contain the rearranged, neurotropic type sequences and thus, the possibility arises that the brain is also a site of latency [29, 99, 141]. Repeated detection of neurotropic viruses in multiple organs of carrier individuals stimulated arguments against the archetype hypothesis. Importantly, pediatric patients with congenital immunosuppression display progressive multifocal leukoencephalopathy in which both archetype and neurotropic type viruses are present in different tissues. These data have been interpreted to mean that in some patients, demyelinating disease may develop after a primary infection rather than requiring a latency period [93, 94]. The archetype hypothesis has been widely accepted and indeed, the disease may occur by transformation from the archetype to neurotropic type. However, at least one alternative possibility remains, i.e. that neurotropic type viruses also circulate in normal human populations and moreover, may cause demyelinating disease upon primary infection (Fig. 4b). 
a

a archetype

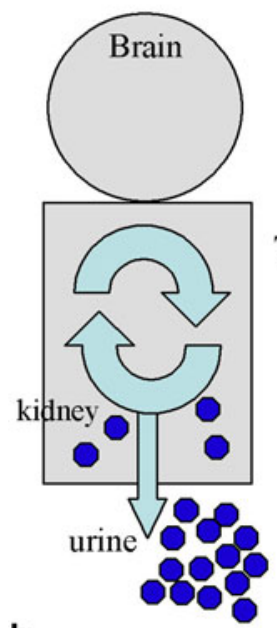

b

Individuals without demyelinating disease (AIDS, non-AIDS)

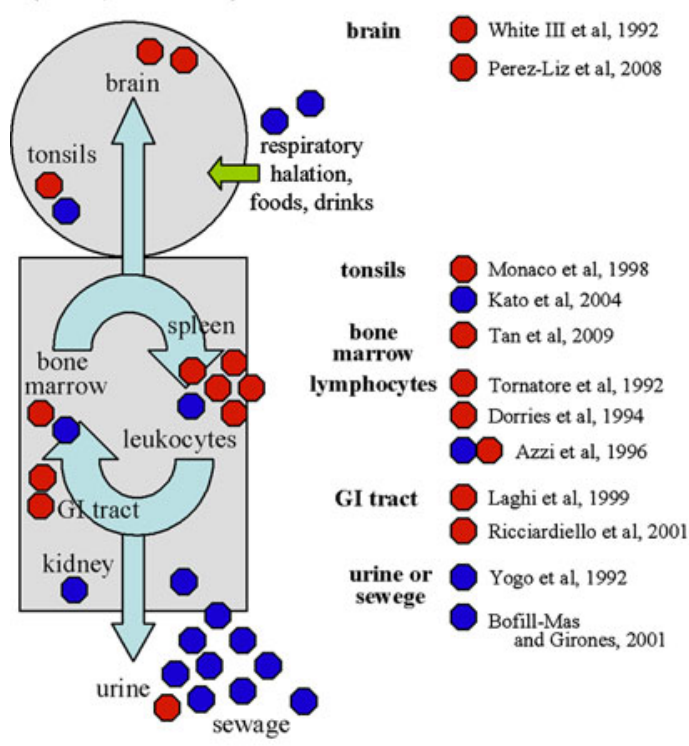

Fig. 4 The archetype hypothesis. a Archetypal viruses are frequently detected in the urine of healthy individuals, whereas neurotropic types are detected in the brains with progressive multifocal leukoencephalopathy. Thus, the archetypal viruses, which are ubiquitous in the human population, may occasionally transform into the neurotropic type, resulting in development of opportunistic demyelinating disease. b Detection of the archetype and neurotropic type in multiple tissues of carrier individuals has raised questions about the archetype hypothesis. See text for a detailed discussion

\section{Nuclear factors define JC virus neurotropism}

Today, we know that JC virus infection is not specific to oligodendrocytes, as viral DNA or proteins have been repeatedly detected in multiple tissues. However, the disease-state outcome of infection, progressive multifocal leukoencephalopathy, selectively occurs in human oligodendroglias. Why JC virus establishes its most efficient lytic infection in this specific cell type and not others remains largely an open question.

The life cycle of polyomaviruses is comprised of early and late events. During early events, viral infection is initiated by attachment to a cell surface receptor, followed by trafficking from the cell membrane toward the nucleus. Next, $T$ antigens are synthesized, and they assist replication of viral genomic DNAs in the nucleus. During late events, the viral capsid proteins VP1, VP2, and VP3 are synthesized in the cytoplasm, and they localize to the nucleus for production of viral progeny. Finally, viral progeny are released from the cells, at which time they can go onto infect additional host cells (Fig. 5a). Cellular susceptibility for lytic infection can be determined at any stage in the lytic cycle.

JC virus can bind to receptors present on a variety of cell types, but progeny production does not necessarily occur in all cell types. Viral entry is mediated by a ubiquitous
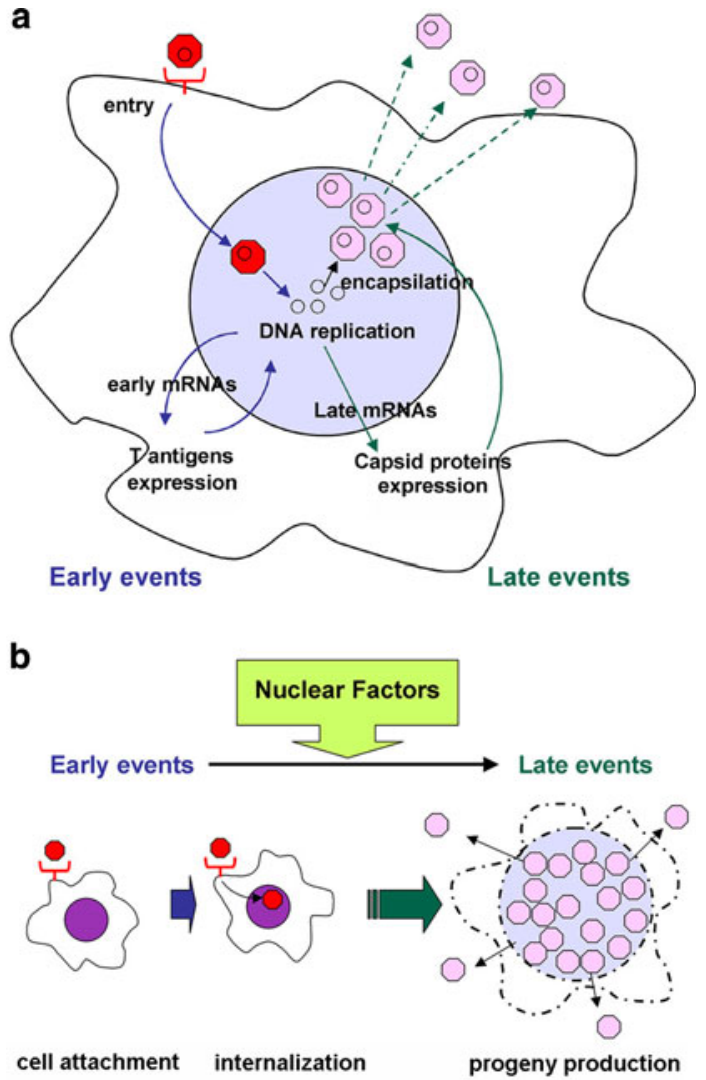

Fig. 5 What determines JC virus neurotropism? a The viral life cycle begins with binding to cell surface receptors and is completed by the release of progeny from the host cell. Cellular susceptibility, for efficient production of viral progeny, can be regulated at any stage in the lytic cycle. b Although JC virus is now known to infect a variety of cells, the most efficient progeny production appears to occur in oligodendroglias, a phenomenon thought to be determined by multiple nuclear factors 
receptor, an $N$-linked glycoprotein with $\alpha(2-6)$-linked sialic acids, which associates with the serotonergic receptor 5HT2A on human glial cells [35, 81]. However, even when the virus attaches to cell surface receptors, or penetrates and reaches the nucleus, these events may not always lead to completion of the viral lytic cycle. The results of in vitro experiments demonstrated that JC virus entry into nuclei was observed for 15 different types of cell lines, but among them, virus replication occurred exclusively in human neuroblastoma cells [126]. The data indicate that the presence of cell surface receptors is essential but does not specifically determine cellular susceptibility for efficient lytic infection [34, 139] (Fig. 5b).

The 98-bp tandem repeats in the regulatory sequence of Mad-1 were found to be a transcriptional regulatory element with enhancer-like activity in human glial cells [65]. Since then, the results of many studies have supported the idea that restricted lytic infection by JC virus in human brain tissue depends on the presence of nuclear factors that are predominantly expressed in glial cells. The rearranged sequence of the regulatory regions markedly affects the levels of viral transcription and replication, as they encode binding sites for nuclear proteins that regulate viral DNA replication or transcriptional activity. The sequences include the TATA box, and binding sites for nuclear transactivators, including Sp1, YB1, sup2, NF-кB, Pura, Tst-1, c-Jun, and NF-1 (reviewed in [102]). Thus, efficient lytic infection in specific cells seems to be dependent on multiple nuclear factors that selectively bind to the rearranged regulatory sequence.

Interestingly, recent studies have revealed that JC virus also infects neurons in cerebellar granule layers and even pyramidal neurons in the cerebral cortex. In the cerebellum, lytic infection of granule cells was proposed as JCV granule cell neuronopathy, and in the cerebral cortex, fulminant JC virus encephalopathy [73, 143, 144]. These data suggest that efficient lytic infection proceeds even in neuronal cells, a process less well understood than lytic infection in glial cells.

PML-NBs as an intranuclear target for JC virus infection

Since establishment of a eukaryotic expression system to generate virus-like particles (VLPs) [119], we have been studying the molecular mechanisms underlying how JC virus develops intranuclear inclusions. The JC virus capsid would be composed of VP1, VP2, and VP3, likely in a specific ratio as in SV40 [80]. Proportional expression of the capsid proteins is in part regulated by alternative splicing, and at least four species of late RNAs are produced (M1-M4) [116]. Of these, it is M1 that encodes VP2/ VP3 and M2 that encodes VP1, which is downstream of agnoprotein (Fig. 6) (note that because the complete amino acid sequence of VP3 is identical to the C-terminal twothirds of VP2, we refer to them collectively as VP2/VP3).

Nuclear proteins typically contain nuclear localization signals (NLSs), most commonly a stretch of basic amino acids such as $\mathbf{K}$ (lysine) and $\mathbf{R}$ (arginine). JC virus VP1 is inefficient in nuclear transport, which is attributable to what is presumably a weak NLS in its N-terminal sequence, MAPTKRKGERKD. This sequence has the properties of an NLS; namely, basic amino acids $\left(\mathbf{K}^{\mathbf{5}} \mathbf{R}^{\mathbf{6}} \mathbf{K}^{7}\right.$ and $\mathbf{R}^{10} \mathbf{K}^{11}$ ) flank the intervening residues GE (superscripts indicate the positions of residues in an amino acid sequence). This can be compared with SV40 VP1, which includes the sequence MAPTKRKGSCPGAAPKKPKE (including $\mathbf{K}^{\mathbf{5}} \mathbf{R}^{\mathbf{6}} \mathbf{K}^{\mathbf{7}}$ and $\mathbf{K}^{\mathbf{1 6}} \mathbf{K}^{\mathbf{1 7}}, \mathbf{K}^{\mathbf{1 9}}$ ), which functions as an efficient, bipartite NLS [58]. It stands to reason, then, that with its functionally weak NLS, JC virus VP1 is distributed in both the cytoplasm and the nucleus, whereas with its efficient NLS, SV40 VP1 is exclusively localized to the nucleus. Exclusive nuclear localization of JC virus VP1 can be achieved upon co-expression with VP2/VP3, which contains two clusters of basic amino acids in the C-terminal region, GPNKKKRRK (cluster 1) and KRRSRSSRS (cluster 2). These sequences compensate for the inefficient nuclear targeting of VP1.

Interestingly, co-transported capsid proteins were found to accumulate at dot-shaped subnuclear domains preferentially detected at the nuclear periphery; that is, at PML-NBs. Confocal microscopic analysis has clearly demonstrated co-localization of VP1 with PML protein, a major component of PML-NBs. Co-localization in a dotshaped distribution pattern was observed both in human brain tissues with progressive multifocal leukoencephalopathy and in COS-7 cells producing VLPs. In the nuclei, major and minor capsid proteins were found to stretch their intranuclear distributions along nuclear matrix-like structures (Fig. 7a, b).

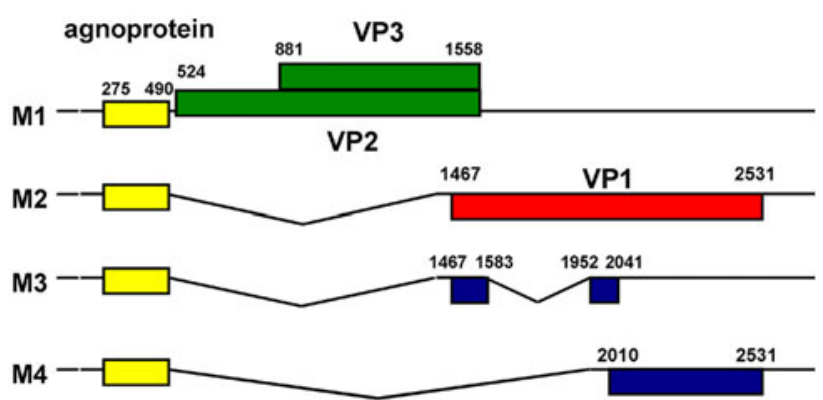

Fig. 6 Structures of JC virus late RNAs. Expression of major capsid protein VP1 and minor capsid proteins VP2/VP3 is kept roughly proportional by alternative splicing. VP1 is encoded on the M2 RNA, and VP2/VP3 on M1, downstream of the agnoprotein. Diagram based on Shishido-Hara et al. [116] (used with permission) 
By electron microscopy, along with viral gene manipulation in COS-7 cells, we have revealed that in the presence of VP2/VP3, colloidal gold particles representing the VP1 epitopes were clustered along the inner nuclear periphery, where numerous VLPs with both round and filamentous structures were also observed. The data are consistent with what has been seen for JC virus-infected glial cells in human brain (Fig. 8). Altogether, it appears that major and minor capsid proteins move cooperatively from the cytoplasm to the nucleus and then accumulate in PML-NBs, where they are assembled into progeny virions (Fig. 9).

What is the mechanism of JC virus-mediated cell death?

The mechanisms of JC virus-mediated cell death remain largely unclear. JC virus-infected cells may undergo apoptosis [108, 145]. However, this is in contrast with another report, in which the authors suggest that JC virusmediated cell death is a non-apoptotic, necrotic mode of death in progenitor-derived astrocyte cell culture [114]. A recent study also demonstrated higher expression of the anti-apoptotic protein survivin, and the authors claimed that viral-infected cells are anti-apoptotic, allowing for completion of the viral lytic cycle [100].

During development of full viral inclusions, PML-NBs may go on to disrupted $[117,118]$, and our current thinking is that disruption or even dysfunction of PML-NBs may induce JC virus-mediated cell death. Indeed, disruption or dysfunction of PML-NBs is associated with a variety of human diseases, including cancers, neurodegenerative disorders, and viral infections, as described below.

\section{PML-NBs and human diseases}

PML-NBs, also known as PML oncogenic domains or nuclear domain 10 (ND10), are dynamic, macromolecular, dot-shaped structures that are ubiquitously present in eukaryotic cells (recent reviews in $[10,20,30,103]$ ).
Fig. 7 JC viral capsid proteins accumulate at PML-NBs in human brain tissue and COS-7 cells. JC virus capsid protein VP1 co-localizes in dots with the PML protein, a major component of PML-NBs. This was observed both in a human brain with progressive multifocal leukoencephalopathy (a) and in COS-7 cells producing VLPs (b top). Both VP1 and VP2/VP3 were distributed within the nucleus, associated with matrix-like structures (b bottom). a, b Top are from Shishido-Hara et al. [118] (used with permission)

\section{a Progressive Multifocal Leukoencephalopathy}
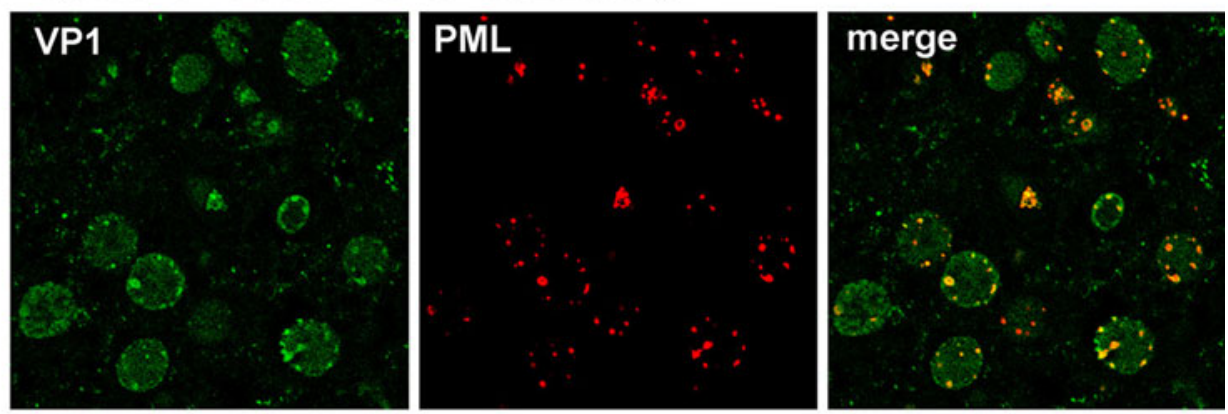

b COS-7 cell produsing VLPs
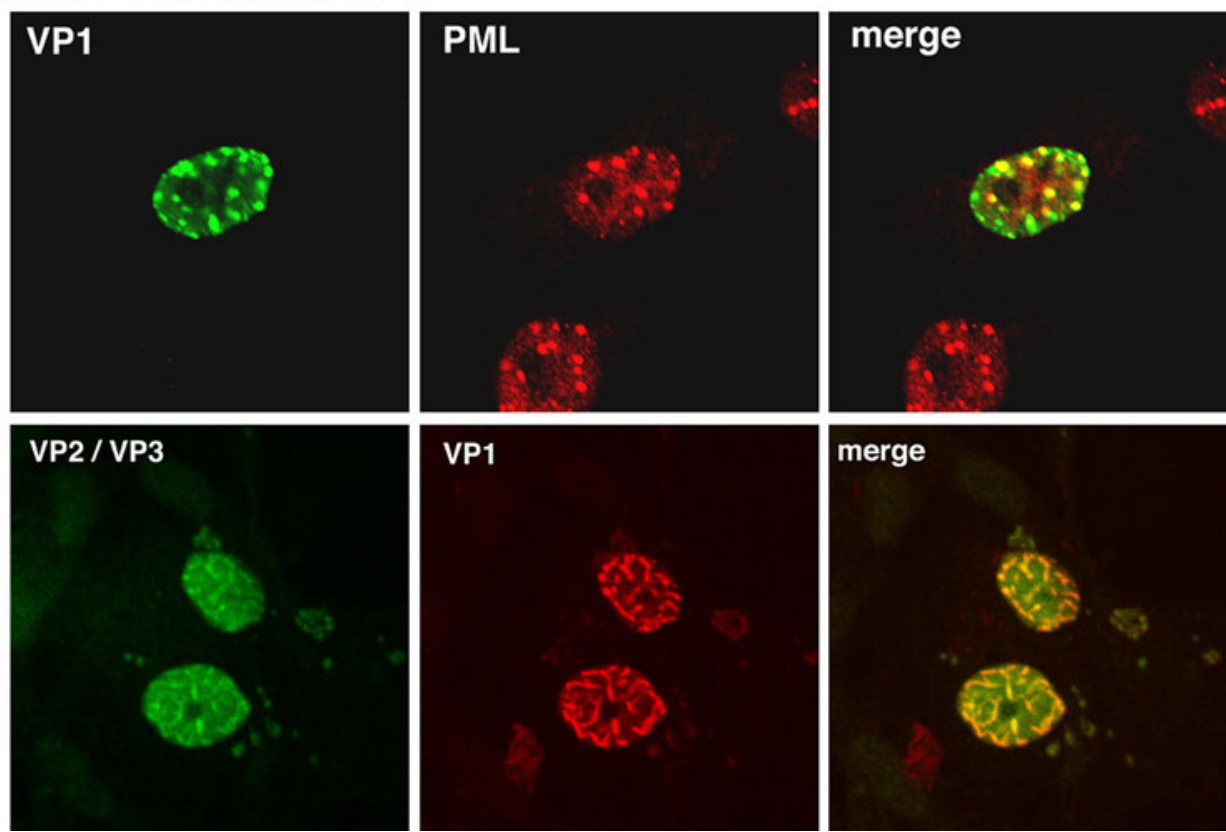


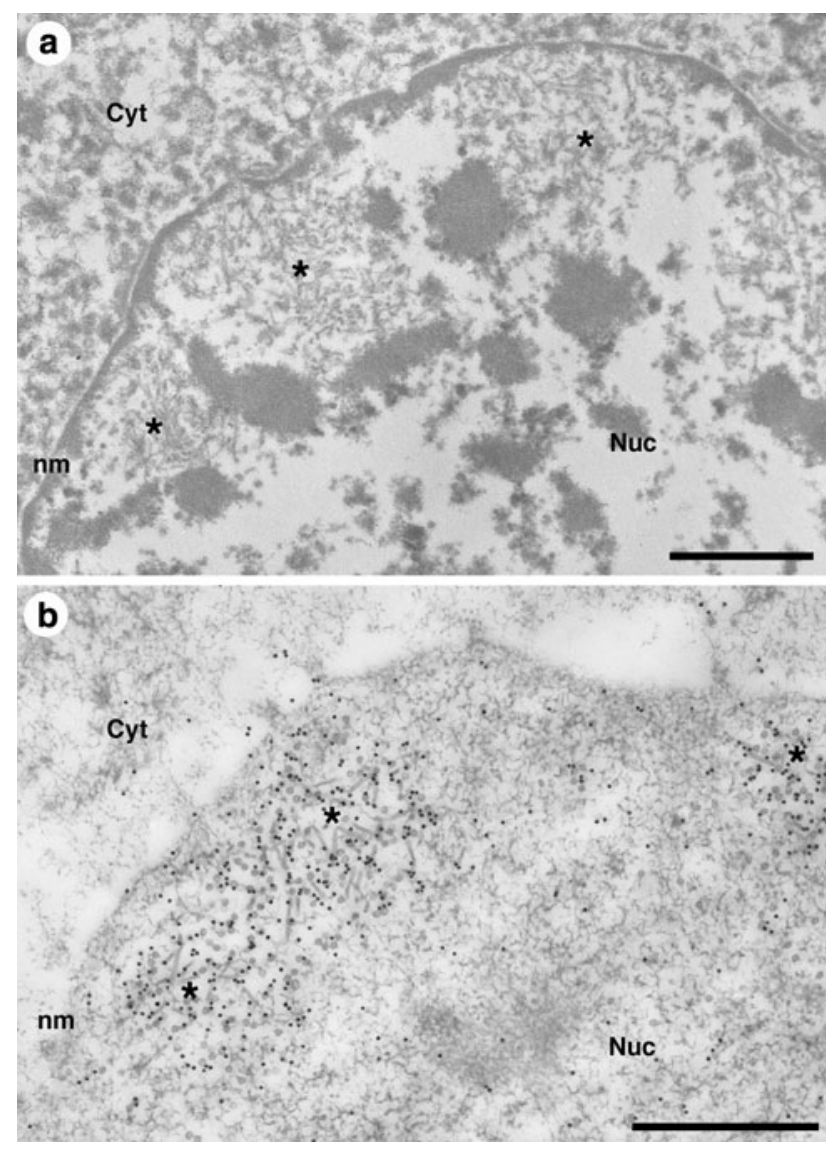

Fig. 8 Electron micrographs of JC virions in human brain tissues and of VLPs in COS-7 cells. a In human brain tissue with progressive multifocal leukoencephalopathy, electron microscopy reveals clustered native virions of both round and filamentous structures at the inner nuclear periphery, indicative of PML-NBs. b Consistently, in cultured cell lines producing VLPs, immunogold labeling VP1 epitopes is clustered at the nuclear periphery, where assembly of VLPs of both round and filamentous structures is detected (Bar $1 \mu \mathrm{m}$ ). Both panels are from Shishido-Hara et al. [117] (used with permission)

PML-NBs relate to important nuclear functions, including cell cycle regulation, DNA replication, repair, transcription, apoptosis, and senescence. PML-NBs vary both in size and in number, depending on the cell cycle phase and differentiation state of the cell, and in response to cellular stress [30, 132]. In cells cultured in vitro, PML-NBs are generally few and smallest in G0, and more numerous and larger when in S phase. PML-NBs are re-established in G1 after mitosis. PML-NBs are structurally and functionally heterogeneous, and nuclear proteins including p53, CBP/ p300, Daxx, BLM, Pin1, HDAC7, and pRB traffic in and out, depending on both normal and pathological conditions. PML protein expression is frequently up-regulated in activated cells [44].

The pathogenic significance of PML-NBs was first indicated in acute promyelocytic leukemia, wherein the

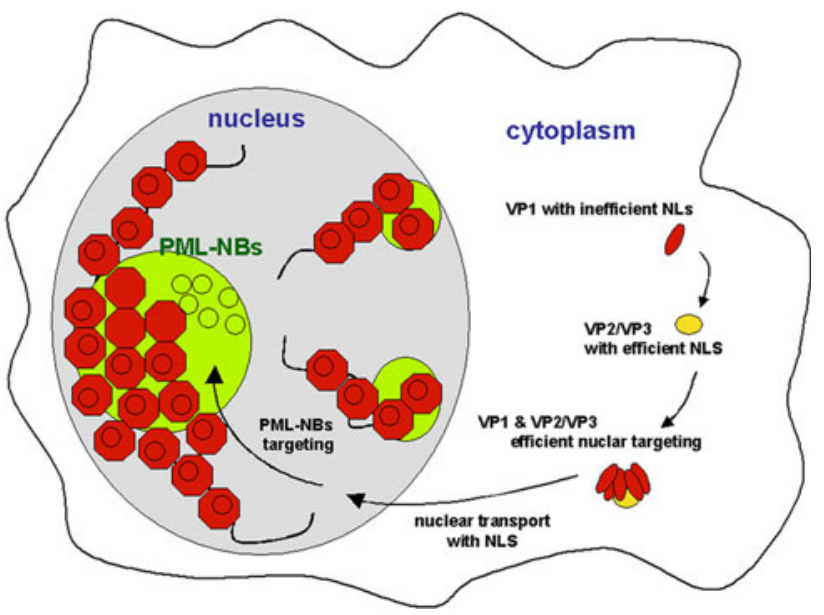

Fig. 9 Schematic illustration of late events in the JC virus life cycle. VP1 may associate with VP2/VP3, and they are co-transported to the nucleus. Complexes of VP1 and VP2/VP3 are assembled into progeny virions at PML-NBs, and likely spread throughout the nucleoplasm, along with matrix-like structures

PML gene is fused to the retinoic acid receptor $\alpha(\mathrm{RAR} \alpha)$ gene due to $t(15 ; 17)$ chromosomal translocation, resulting in disruption of PML-NBs [23, 47, 60]. Subsequent to this finding, the PML protein and PML-NBs were studied extensively in relation to tumorigenesis, both in basic research studies and in the clinic. PML-NBs are sites of tumor suppression, where PML protein and p53 function cooperatively [50, 111]. PML protein expression is reduced or abolished in human cancers of various histologic origins, including prostate, colon, breast, lung, lymphomas, CNS tumors, and germ cell tumors [53]. Interestingly, PML-NBs interact with particularly gene-rich and transcriptionally active regions of chromatin, including the TP53 locus that encodes p53 [125]. Therefore, the PML protein as well as PML-NBs has significant functions for tumor suppression, especially as associated with p53. Thus, their dysfunction or disruption likely relate to both oncogenesis and tumor progression.

Polyglutamine diseases such as Huntington's disease and spinocerebellar ataxias are neurological diseases characterized by genetic mutations of expanded CAG repeats that encode polyglutamines (polyQ). The mutant proteins with expanded polyQ tracts accumulate in the nucleus and form neuronal intranuclear inclusions (NIIs). NIIs are frequently associated with PML-NBs [128, 129]. The results of in vitro experiments show that the matrixassociated PML-NB structures are disrupted by polyQ mutant proteins $[64,123]$. Thus, the presence of NIIs may cause disordered nuclear functions, such as altered or impaired transcription, as well as induce cell death or degeneration of neuronal cells $[42,96]$. Moreover, much interest has been focused on understanding the role of PML-NBs in protein storage and ubiquitin-mediated 
degradation by proteasomes $[59,92]$. A model was proposed wherein PML-NBs scan the nucleus in search of misfolded proteins and promote degradation of these errant proteins via the proteasome. However, it is not yet clear if the presence of NIIs is pernicious, coincidental, or beneficial for neuronal cells [71, 112, 122].

A variety of viruses target PML-NBs, including herpes simplex virus type-1 (HSV-1), human cytomegalovirus (HCMV), Epstein-Barr virus (EBV), papillomaviruses, and polyomaviruses. These viruses may alter components of PML-NBs, regulate expression and localization of PML protein, and even disrupt PML-NB structure (recent review in [131]). For example, HSV-1, HCMV, and EBV all disrupt PML-NBs during early events of viral replication, whereas human papillomavirus type 33 (HPV33) reorganizes PMLNB components and utilizes them for efficient capsid assembly during late events [39, 40]. Expression of PML protein is up-regulated after treatment with interferon (IFN), suggesting that PML-NBs would be an anti-viral structure [38]. Recent data, however, also indicate that PML-NBs are at least in part pro-viral, and facilitate latency in HSV-1 and HCMV infection [110]. As we understand it today, progressive multifocal leukoencephalopathy is a JC virusinduced demyelinating disorder of the nervous system, in which PML-NBs are the targets for viral infection. How PML-NBs are involved in or utilized for JC virus infection is the next issue that will be addressed (Fig. 10a).

\section{Does JC virus induce brain tumors in humans?}

Finally, we reconsider a long-lasting question asked since the discovery of JC virus, Can JC virus induce brain tumors in humans? This question has been raised many times, as the virus-induced brain tumors in experimental animals, and viral DNA or proteins were repeatedly detected in human tumor tissue (reviewed in $[66,104,142]$ and others). In 1970s, it was shown that JC virus inoculated into experimental animals can induce brain tumors [82, 137]. The JC virus Tokyo-1 strain was shown to induce medulloblastoma in hamsters [91]. Indeed, JC virus was highly oncogenic and capable of inducing various types of brain tumors in these animals, including glioblastomas, medulloblastomas, neuroblastomas, pineocytomas, and/or other tumors of central nervous system. In 1999 and 2000, transgenic mice were generated in which the early regions of the archetype or neurotropic type are presented, and both were capable of inducing medulloblastoma/primitive neuroectodermal tumor (PNET) and pituitary neoplasia [49, 75]. Thus, there is no doubt in that JC virus is oncogenic to experimental animals.

From the late 1990s to the early 2000s, a number of reports described detection of JC virus, a viral DNA genome or

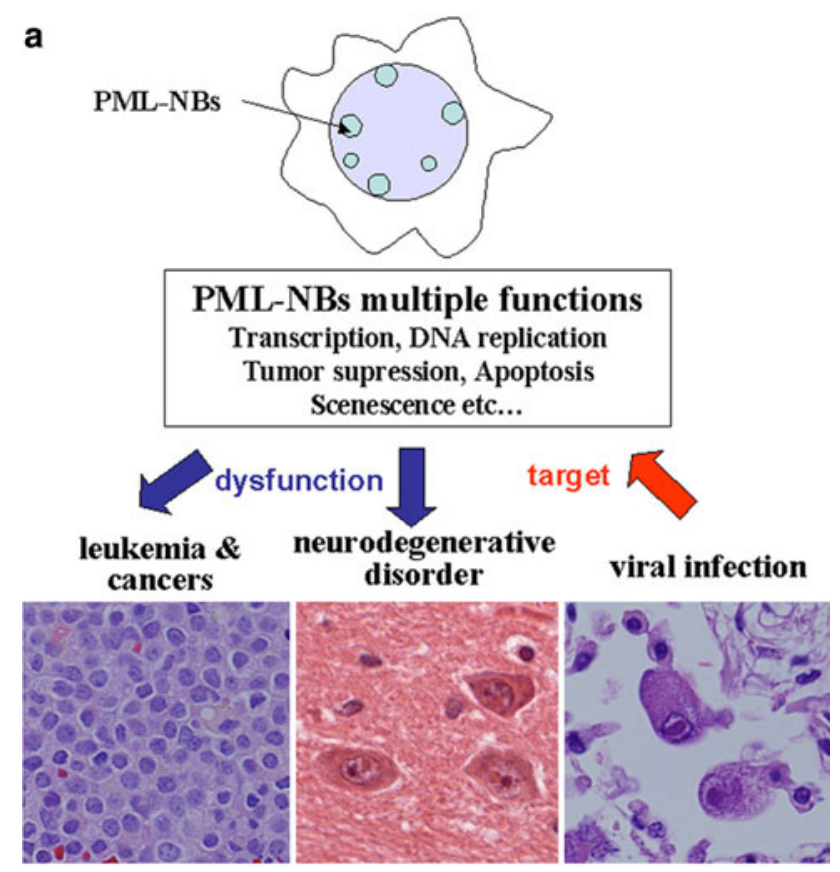

b

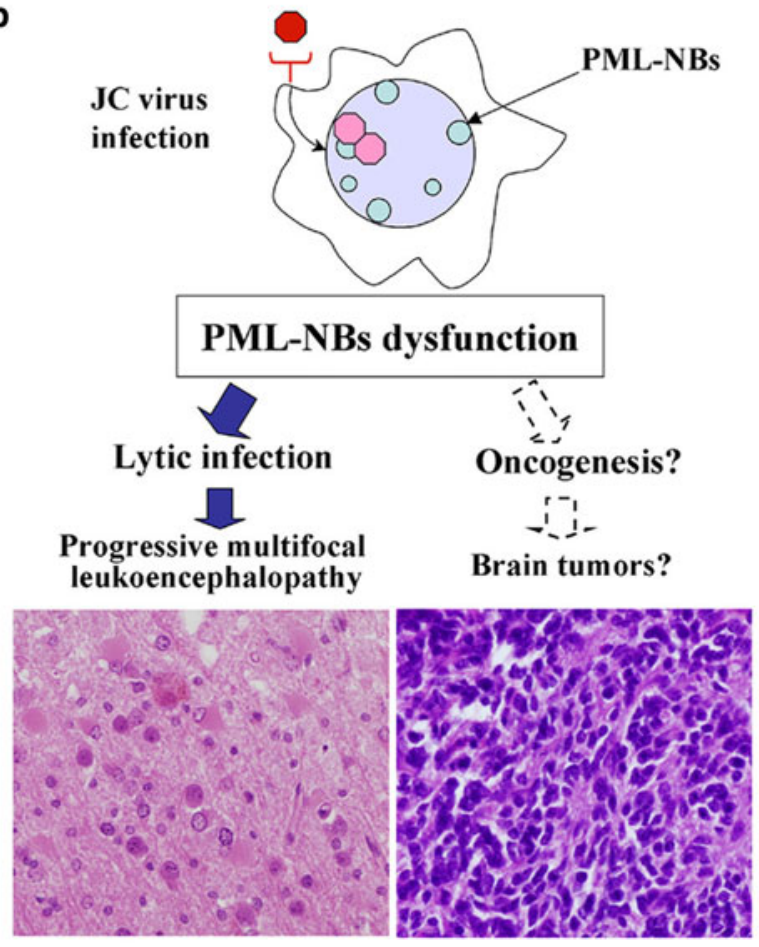

Fig. 10 Does JC virus induce brain tumors in humans? a PML-NBs are the sites of multiple nuclear functions, and disruption or dysfunction of PML-NBs can cause a variety of human diseases, including leukemia and other cancers, as well as neurodegenerative disorders. Many viruses target PML-NBs. b JC virus-induced brain tumors are observed in experimental animals but whether or not this is clinically true in humans remains at issue

oncogenic $\mathrm{T}$ antigen, in human clinical samples. JC virus has been detected in brain tumors of different histological types, including medulloblastoma, astrocytoma, oligodendroglioma, 
oligoastrocytoma, anaplastic astrocytoma, anaplastic oligodendroglioma, glioblastoma, ependymoma, and primary CNS lymphoma [18, 24-27, 74, 105]. The virus has also been detected in colorectal, gastric and esophageal cancers, and even in lung cancers $[1,28,37,77,89,107,149]$. However, it is difficult to know if the virus is causative for human tumors, as JC virus is ubiquitously prevalent in the human population and has been detected in multiple tissues, including the unaffected brains, as described earlier. In addition, some groups have reported discordant results suggesting that JC virus is unlikely to be linked to oncogenesis in medulloblastoma or PNET $[54,68,138]$, and in oligodendroglioma or astrocytoma [55]. Thus, it is not yet clear if JC virus infection causes malignant tumors in humans.

In progressive multifocal leukoencephalopathy, the glial cells with enlarging nuclei seem markedly activated in their cell cycle, with distinct expression of MIB-1 (Ki-67), proliferating cell nuclear antigen (PCNA), cyclin A and cyclin $\mathrm{B} 1[3,4,78]$. The results of microarray analysis also demonstrate enhanced transcription of the cyclin A and B1 genes [101]. Despite relatively high MIB-1 expression, however, mitotic figures have not been observed. Thus, JC virus likely first activates host cells in their cell cycle, which is presumably advantageous for viral progeny production, but before completion, the cycle is dysregulated or blocked. To address the persisting question if JC virus can induce malignant tumors in humans, it might be useful to clarify how cell fate is determined in infected cells and separated into lytic infection versus malignant transformation. We expect that studies on PML-NBs might provide interesting clues that could increase our understanding in the future (Fig. 10b).

\section{Conclusions}

Neuropathology of progressive multifocal leukoencephalopathy has diverged with the expanded clinical spectrum of underlying diseases. Nevertheless, studies on JC virus biology have advanced our understanding of this demyelinating disorder. Nuclear viral inclusions in the form of either full inclusions or dot-shaped inclusions are present in the enlarged nuclei of glial cells, and PML-NBs have been identified as an intranuclear target of JC virus infection. We hope future studies on PML-NBs may provide clues as to how fate is determined in JC virus-infected cells, as well as insight into JC virus-mediated lytic infection or malignant transformation.

Acknowledgments I thank all of my past and present colleagues and collaborators. Special thanks to Drs. Toshiki Uchihara (Tokyo Metropolitan Institute of Neuroscience) and Hidehiro Mizusawa (Tokyo Medical and Dental University). This work, as well as some of the original research studies discussed herein, was supported by grants for Research on Measures for Intractable Diseases (Prion Disease and Slow Virus Infection) from the Ministry of Health, Labour and Welfare of Japan.

Open Access This article is distributed under the terms of the Creative Commons Attribution Noncommercial License which permits any noncommercial use, distribution, and reproduction in any medium, provided the original author(s) and source are credited.

\section{References}

1. Abdel-Aziz HO, Murai Y, Hong M et al (2007) Detection of the JC virus genome in lung cancers: possible role of the T-antigen in lung oncogenesis. Appl Immunohistochem Mol Morphol $15: 394-400$

2. Angelini L, Pietrogrande MC, Delle Piane MR et al (2001) Progressive multifocal leukoencephalopathy in a child with hyperimmunoglobulin $\mathrm{E}$ recurrent infection syndrome and review of the literature. Neuropediatrics 32:250-255

3. Ariza A, Mate JL, Fernandez-Vasalo A et al (1994) p53 and proliferating cell nuclear antigen expression in JC virus-infected cells of progressive multifocal leukoencephalopathy. Hum Pathol 25:1341-1345

4. Ariza A, Mate JL, Isamat M, Calatrava A, Fernandez-Vasalo A, Navas-Palacios JJ (1998) Overexpression of Ki-67 and cyclins $\mathrm{A}$ and $\mathrm{B} 1$ in JC virus-infected cells of progressive multifocal leukoencephalopathy. J Neuropathol Exp Neurol 57:226-230

5. Astrom KE, Mancall EL, Richardson EP Jr (1958) Progressive multifocal leuko-encephalopathy; a hitherto unrecognized complication of chronic lymphatic leukaemia and Hodgkin's disease. Brain 81:93-111

6. Azzi A, De Santis R, Ciappi S et al (1996) Human polyomaviruses DNA detection in peripheral blood leukocytes from immunocompetent and immunocompromised individuals. J Neurovirol 2:411-416

7. Berger JR (2007) Progressive multifocal leukoencephalopathy. Curr Neurol Neurosci Rep 7:461-469

8. Berger JR, Pall L, Lanska D, Whiteman M (1998) Progressive multifocal leukoencephalopathy in patients with HIV infection. J Neurovirol 4:59-68

9. Bernal-Cano F, Joseph JT, Koralnik IJ (2007) Spinal cord lesions of progressive multifocal leukoencephalopathy in an acquired immunodeficiency syndrome patient. J Neurovirol 13:474-476

10. Bernardi R, Pandolfi PP (2007) Structure, dynamics and functions of promyelocytic leukaemia nuclear bodies. Nat Rev Mol Cell Biol 8:1006-1016

11. Bienfait HP, Louwerse ES, Portegies P, van der Meer JT (1998) Progressive multifocal leukoencephalopathy presenting as a solitary gray matter lesion. J Neurol 245:557-558

12. Bofill-Mas S, Clemente-Casares P, Major EO, Curfman B, Girones R (2003) Analysis of the excreted JC virus strains and their potential oral transmission. J Neurovirol 9:498-507

13. Bofill-Mas S, Formiga-Cruz M, Clemente-Casares P, Calafell F, Girones R (2001) Potential transmission of human polyomaviruses through the gastrointestinal tract after exposure to virions or viral DNA. J Virol 75:10290-10299

14. Bofill-Mas S, Girones R (2001) Excretion and transmission of JCV in human populations. J Neurovirol 7:345-349

15. Boren EJ, Cheema GS, Naguwa SM, Ansari AA, Gershwin ME (2008) The emergence of progressive multifocal leukoencephalopathy (PML) in rheumatic diseases. J Autoimmun 30:90-98 
16. Bossolasco S, Calori G, Moretti F et al (2005) Prognostic significance of JC virus DNA levels in cerebrospinal fluid of patients with HIV-associated progressive multifocal leukoencephalopathy. Clin Infect Dis 40:738-744

17. Calabrese LH, Molloy ES, Huang D, Ransohoff RM (2007) Progressive multifocal leukoencephalopathy in rheumatic diseases: evolving clinical and pathologic patterns of disease. Arthritis Rheum 56:2116-2128

18. Caldarelli-Stefano R, Boldorini R, Monga G, Meraviglia E, Zorini EO, Ferrante P (2000) JC virus in human glial-derived tumors. Hum Pathol 31:394-395

19. Cavanagh JB, Greenbaum D, Marshall AH, Rubinstein LJ (1959) Cerebral demyelination associated with disorders of the reticuloendothelial system. Lancet 2:524-529

20. Ching RW, Dellaire G, Eskiw CH, Bazett-Jones DP (2005) PML bodies: a meeting place for genomic loci? J Cell Sci 118:847854

21. Cinque P, Bossolasco S, Brambilla AM et al (2003) The effect of highly active antiretroviral therapy-induced immune reconstitution on development and outcome of progressive multifocal leukoencephalopathy: study of 43 cases with review of the literature. J Neurovirol 9(Suppl 1):73-80

22. Daniel AM, Swenson JJ, Mayreddy RP, Khalili K, Frisque RJ (1996) Sequences within the early and late promoters of archetype JC virus restrict viral DNA replication and infectivity. Virology 216:90-101

23. de The H, Lavau C, Marchio A, Chomienne C, Degos L, Dejean A (1991) The PML-RAR alpha fusion mRNA generated by the $t(15 ; 17)$ translocation in acute promyelocytic leukemia encodes a functionally altered RAR. Cell 66:675-684

24. Del Valle L, Delbue S, Gordon J et al (2002) Expression of JC virus T-antigen in a patient with MS and glioblastoma multiforme. Neurology 58:895-900

25. Del Valle L, Enam S, Lara C, Miklossy J, Khalili K, Gordon J (2004) Primary central nervous system lymphoma expressing the human neurotropic polyomavirus, JC virus, genome. J Virol 78:3462-3469

26. Del Valle L, Gordon J, Assimakopoulou M et al (2001) Detection of JC virus DNA sequences and expression of the viral regulatory protein T-antigen in tumors of the central nervous system. Cancer Res 61:4287-4293

27. Del Valle L, Gordon J, Enam S et al (2002) Expression of human neurotropic polyomavirus JCV late gene product agnoprotein in human medulloblastoma. J Natl Cancer Inst 94:267273

28. Del Valle L, White MK, Enam S et al (2005) Detection of JC virus DNA sequences and expression of viral $\mathrm{T}$ antigen and agnoprotein in esophageal carcinoma. Cancer 103:516-527

29. Delbue S, Branchetti E, Boldorini R et al (2008) Presence and expression of JCV early gene large T Antigen in the brains of immunocompromised and immunocompetent individuals. J Med Virol 80:2147-2152

30. Dellaire G, Bazett-Jones DP (2004) PML nuclear bodies: dynamic sensors of DNA damage and cellular stress. Bioessays 26:963-977

31. Dorries K, Vogel E, Gunther S, Czub S (1994) Infection of human polyomaviruses JC and BK in peripheral blood leukocytes from immunocompetent individuals. Virology 198:59-70

32. Dubois V, Dutronc H, Lafon ME et al (1997) Latency and reactivation of JC virus in peripheral blood of human immunodeficiency virus type 1 -infected patients. J Clin Microbiol 35:2288-2292

33. Dubois V, Lafon ME, Ragnaud JM et al (1996) Detection of JC virus DNA in the peripheral blood leukocytes of HIV-infected patients. Aids 10:353-358
34. Eash S, Tavares R, Stopa EG, Robbins SH, Brossay L, Atwood WJ (2004) Differential distribution of the JC virus receptor-type sialic acid in normal human tissues. Am J Pathol 164:419-428

35. Elphick GF, Querbes W, Jordan JA et al (2004) The human polyomavirus, JCV, uses serotonin receptors to infect cells. Science 306:1380-1383

36. Elsner C, Dorries K (1992) Evidence of human polyomavirus BK and JC infection in normal brain tissue. Virology 191:72-80

37. Enam S, Del Valle L, Lara C et al (2002) Association of human polyomavirus JCV with colon cancer: evidence for interaction of viral T-antigen and beta-catenin. Cancer Res 62:7093-7101

38. Everett RD, Chelbi-Alix MK (2007) PML and PML nuclear bodies: implications in antiviral defence. Biochimie 89:819-830

39. Florin L, Sapp C, Streeck RE, Sapp M (2002) Assembly and translocation of papillomavirus capsid proteins. J Virol 76:10009-10014

40. Florin L, Schafer F, Sotlar K, Streeck RE, Sapp M (2002) Reorganization of nuclear domain 10 induced by papillomavirus capsid protein 12. Virology 295:97-107

41. Frisque RJ, Bream GL, Cannella MT (1984) Human polyomavirus JC virus genome. J Virol 51:458-469

42. Fu L, Gao YS, Sztul E (2005) Transcriptional repression and cell death induced by nuclear aggregates of non-polyglutamine protein. Neurobiol Dis 20:656-665

43. Gallia GL, Houff SA, Major EO, Khalili K (1997) Review: JC virus infection of lymphocytes-revisited. J Infect Dis 176:16031609

44. Gambacorta M, Flenghi L, Fagioli M et al (1996) Heterogeneous nuclear expression of the promyelocytic leukemia (PML) protein in normal and neoplastic human tissues. Am J Pathol 149:2023-2035

45. Garcia-Suarez J, de Miguel D, Krsnik I, Banas H, Arribas I, Burgaleta $C$ (2005) Changes in the natural history of progressive multifocal leukoencephalopathy in HIV-negative lymphoproliferative disorders: impact of novel therapies. Am J Hematol 80:271-281

46. Giudici B, Vaz B, Bossolasco S et al (2000) Highly active antiretroviral therapy and progressive multifocal leukoencephalopathy: effects on cerebrospinal fluid markers of JC virus replication and immune response. Clin Infect Dis 30:95-99

47. Goddard AD, Borrow J, Freemont PS, Solomon E (1991) Characterization of a zinc finger gene disrupted by the $t(15 ; 17)$ in acute promyelocytic leukemia. Science 254:1371-1374

48. Goldberg SL, Pecora AL, Alter RS et al (2002) Unusual viral infections (progressive multifocal leukoencephalopathy and cytomegalovirus disease) after high-dose chemotherapy with autologous blood stem cell rescue and peritransplantation rituximab. Blood 99:1486-1488

49. Gordon J, Del Valle L, Otte J, Khalili K (2000) Pituitary neoplasia induced by expression of human neurotropic polyomavirus, JCV, early genome in transgenic mice. Oncogene 19:4840-4846

50. Gottifredi V, Prives C (2001) P53 and PML: new partners in tumor suppression. Trends Cell Biol 11:184-187

51. Gray F, Bazille C, Adle-Biassette H, Mikol J, Moulignier A, Scaravilli F (2005) Central nervous system immune reconstitution disease in acquired immunodeficiency syndrome patients receiving highly active antiretroviral treatment. J Neurovirol 11(Suppl 3):16-22

52. Gray F, Chretien F, Vallat-Decouvelaere AV, Scaravilli F (2003) The changing pattern of HIV neuropathology in the HAART era. J Neuropathol Exp Neurol 62:429-440

53. Gurrieri C, Capodieci P, Bernardi R et al (2004) Loss of the tumor suppressor PML in human cancers of multiple histologic origins. J Natl Cancer Inst 96:269-279 
54. Hayashi H, Endo S, Suzuki S et al (2001) JC virus large T protein transforms rodent cells but is not involved in human medulloblastoma. Neuropathology 21:129-137

55. Herbarth B, Meissner H, Westphal M, Wegner M (1998) Absence of polyomavirus JC in glial brain tumors and gliomaderived cell lines. Glia 22:415-420

56. Hogg RS, O'Shaughnessy MV, Gataric N et al (1997) Decline in deaths from AIDS due to new antiretrovirals. Lancet 349:1294

57. Houff SA, Major EO, Katz DA et al (1988) Involvement of JC virus-infected mononuclear cells from the bone marrow and spleen in the pathogenesis of progressive multifocal leukoencephalopathy. N Engl J Med 318:301-305

58. Ishii N, Minami N, Chen EY, Medina AL, Chico MM, Kasamatsu H (1996) Analysis of a nuclear localization signal of simian virus 40 major capsid protein Vp1. J Virol 70:1317-1322

59. Janer A, Martin E, Muriel MP et al (2006) PML clastosomes prevent nuclear accumulation of mutant ataxin-7 and other polyglutamine proteins. J Cell Biol 174:65-76

60. Kakizuka A, Miller WH Jr, Umesono K et al (1991) Chromosomal translocation $t(15 ; 17)$ in human acute promyelocytic leukemia fuses RAR alpha with a novel putative transcription factor, PML. Cell 66:663-674

61. Kastrup O, Maschke M, Diener HC, Wanke I (2002) Progressive multifocal leukoencephalopathy limited to the brain stem. Neuroradiology 44:227-229

62. Kastrup O, Wanke I, Esser S, Maschke M (2005) Evolution of purely infratentorial PML under HAART: negative outcome under rapid immune reconstitution. Clin Neurol Neurosurg 107:509-513

63. Kato A, Kitamura T, Takasaka T et al (2004) Detection of the archetypal regulatory region of JC virus from the tonsil tissue of patients with tonsillitis and tonsilar hypertrophy. J Neurovirol 10:244-249

64. Kaytor MD, Duvick LA, Skinner PJ, Koob MD, Ranum LP, Orr HT (1999) Nuclear localization of the spinocerebellar ataxia type 7 protein, ataxin-7. Hum Mol Genet 8:1657-1664

65. Kenney S, Natarajan V, Strike D, Khoury G, Salzman NP (1984) $\mathrm{JC}$ virus enhancer-promoter active in human brain cells. Science 226:1337-1339

66. Khalili K, Del Valle L, Otte J, Weaver M, Gordon J (2003) Human neurotropic polyomavirus, JCV, and its role in carcinogenesis. Oncogene 22:5181-5191

67. Kharfan-Dabaja MA, Ayala E, Greene J, Rojiani A, Murtagh FR, Anasetti C (2007) Two cases of progressive multifocal leukoencephalopathy after allogeneic hematopoietic cell transplantation and a review of the literature. Bone Marrow Transplant 39:101-107

68. Kim JY, Koralnik IJ, LeFave M, Segal RA, Pfister LA, Pomeroy SL (2002) Medulloblastomas and primitive neuroectodermal tumors rarely contain polyomavirus DNA sequences. Neuro Oncol 4:165-170

69. Kitamura T, Aso Y, Kuniyoshi N, Hara K, Yogo Y (1990) High incidence of urinary JC virus excretion in nonimmunosuppressed older patients. J Infect Dis 161:1128-1133

70. Kleinschmidt-DeMasters BK, Tyler KL (2005) Progressive multifocal leukoencephalopathy complicating treatment with natalizumab and interferon beta-1a for multiple sclerosis. $\mathrm{N}$ Engl J Med 353:369-374

71. Klement IA, Skinner PJ, Kaytor MD et al (1998) Ataxin-1 nuclear localization and aggregation: role in polyglutamineinduced disease in SCA1 transgenic mice. Cell 95:41-53

72. Knowles WA, Pipkin P, Andrews N et al (2003) Populationbased study of antibody to the human polyomaviruses BKV and JCV and the simian polyomavirus SV40. J Med Virol 71:115123
73. Koralnik IJ, Wuthrich C, Dang X et al (2005) JC virus granule cell neuronopathy: a novel clinical syndrome distinct from progressive multifocal leukoencephalopathy. Ann Neurol 57:576-580

74. Krynska B, Del Valle L, Croul S et al (1999) Detection of human neurotropic JC virus DNA sequence and expression of the viral oncogenic protein in pediatric medulloblastomas. Proc Natl Acad Sci USA 96:11519-11524

75. Krynska B, Otte J, Franks R, Khalili K, Croul S (1999) Human ubiquitous $\mathrm{JCV}(\mathrm{CY}) \mathrm{T}$-antigen gene induces brain tumors in experimental animals. Oncogene 18:39-46

76. Kuchelmeister K, Gullotta F, Bergmann M, Angeli G, Masini T (1993) Progressive multifocal leukoencephalopathy (PML) in the acquired immunodeficiency syndrome (AIDS). A neuropathological autopsy study of 21 cases. Pathol Res Pract 189:163-173

77. Laghi L, Randolph AE, Chauhan DP et al (1999) JC virus DNA is present in the mucosa of the human colon and in colorectal cancers. Proc Natl Acad Sci USA 96:7484-7489

78. Lammie GA, Beckett A, Courtney R, Scaravilli F (1994) An immunohistochemical study of p53 and proliferating cell nuclear antigen expression in progressive multifocal leukoencephalopathy. Acta Neuropathol 88:465-471

79. Langer-Gould A, Atlas SW, Green AJ, Bollen AW, Pelletier D (2005) Progressive multifocal leukoencephalopathy in a patient treated with natalizumab. N Engl J Med 353:375-381

80. Liddington RC, Yan Y, Moulai J, Sahli R, Benjamin TL, Harrison SC (1991) Structure of simian virus 40 at 3.8-A resolution. Nature 354:278-284

81. Liu CK, Wei G, Atwood WJ (1998) Infection of glial cells by the human polyomavirus JC is mediated by an N-linked glycoprotein containing terminal alpha(2-6)-linked sialic acids. J Virol 72:4643-4649

82. London WT, Houff SA, Madden DL et al (1978) Brain tumors in owl monkeys inoculated with a human polyomavirus (JC virus). Science 201:1246-1249

83. Matsuda M, Jona M, Yasui K, Nagashima K (1987) Genetic characterization of JC virus Tokyo-1 strain, a variant oncogenic in rodents. Virus Res 7:159-168

84. Mazlo M, Tariska I (1980) Morphological demonstration of the first phase of polyomavirus replication in oligodendroglia cells of human brain in progressive multifocal leukoencephalopathy (PML). Acta Neuropathol 49:133-143

85. Miralles P, Berenguer J, Lacruz C et al (2001) Inflammatory reactions in progressive multifocal leukoencephalopathy after highly active antiretroviral therapy. Aids 15:1900-1902

86. Moll NM, Rietsch AM, Ransohoff AJ et al (2008) Cortical demyelination in PML and MS: similarities and differences. Neurology 70:336-343

87. Molloy ES, Calabrese LH (2008) Progressive multifocal leukoencephalopathy in patients with rheumatic diseases: are patients with systemic lupus erythematosus at particular risk? Autoimmun Rev 8:144-146

88. Monaco MC, Jensen PN, Hou J, Durham LC, Major EO (1998) Detection of JC virus DNA in human tonsil tissue: evidence for site of initial viral infection. J Virol 72:9918-9923

89. Murai Y, Zheng HC, Abdel Aziz HO et al (2007) High JC virus load in gastric cancer and adjacent non-cancerous mucosa. Cancer Sci 98:25-31

90. Nagashima K, Yamaguchi K, Yasui K, Ogiwara H (1981) Progressive multifocal leukoencephalopathy. Neuropathology and virus isolation. Acta Pathol Jpn 31:953-961

91. Nagashima K, Yasui K, Kimura J, Washizu M, Yamaguchi K, Mori W (1984) Induction of brain tumors by a newly isolated JC virus (Tokyo-1 strain). Am J Pathol 116:455-463 
92. Negorev D, Maul GG (2001) Cellular proteins localized at and interacting within ND10/PML nuclear bodies/PODs suggest functions of a nuclear depot. Oncogene 20:7234-7242

93. Newman JT, Frisque RJ (1997) Detection of archetype and rearranged variants of $\mathrm{JC}$ virus in multiple tissues from a pediatric PML patient. J Med Virol 52:243-252

94. Newman JT, Frisque RJ (1999) Identification of JC virus variants in multiple tissues of pediatric and adult PML patients. J Med Virol 58:79-86

95. Nived O, Bengtsson AA, Jonsen A, Sturfelt G (2008) Progressive multifocal leukoencephalopathy: the importance of early diagnosis illustrated in four cases. Lupus 17:1036-1041

96. Okazawa H (2003) Polyglutamine diseases: a transcription disorder? Cell Mol Life Sci 60:1427-1439

97. Padgett BL, Walker DL (1973) Prevalence of antibodies in human sera against JC virus, an isolate from a case of progressive multifocal leukoencephalopathy. J Infect Dis 127:467470

98. Padgett BL, Walker DL, ZuRhein GM, Eckroade RJ, Dessel BH (1971) Cultivation of papova-like virus from human brain with progressive multifocal leucoencephalopathy. Lancet 1:12571260

99. Perez-Liz G, Del Valle L, Gentilella A, Croul S, Khalili K (2008) Detection of JC virus DNA fragments but not proteins in normal brain tissue. Ann Neurol 64:379-387

100. Pina-Oviedo S, Urbanska K, Radhakrishnan S et al (2007) Effects of JC virus infection on anti-apoptotic protein survivin in progressive multifocal leukoencephalopathy. Am J Pathol 170:1291-1304

101. Radhakrishnan S, Otte J, Enam S, Del Valle L, Khalili K, Gordon J (2003) JC virus-induced changes in cellular gene expression in primary human astrocytes. J Virol 77:1063810644

102. Ravichandran V, Major EO (2006) Viral proteomics: a promising approach for understanding JC virus tropism. Proteomics 6:5628-5636

103. Reineke EL, Kao HY (2009) Targeting promyelocytic leukemia protein: a means to regulating PML nuclear bodies. Int $\mathbf{J}$ Biol Sci 5:366-376

104. Reiss K, Khalili K (2003) Viruses and cancer: lessons from the human polyomavirus, JCV. Oncogene 22:6517-6523

105. Rencic A, Gordon J, Otte J et al (1996) Detection of JC virus DNA sequence and expression of the viral oncoprotein, tumor antigen, in brain of immunocompetent patient with oligoastrocytoma. Proc Natl Acad Sci USA 93:7352-7357

106. Ricciardiello L, Chang DK, Laghi L, Goel A, Chang CL, Boland CR (2001) Mad-1 is the exclusive JC virus strain present in the human colon, and its transcriptional control region has a deleted 98-base-pair sequence in colon cancer tissues. J Virol 75:19962001

107. Ricciardiello L, Laghi L, Ramamirtham P et al (2000) JC virus DNA sequences are frequently present in the human upper and lower gastrointestinal tract. Gastroenterology 119:1228-1235

108. Richardson-Burns SM, Kleinschmidt-DeMasters BK, DeBiasi RL, Tyler KL (2002) Progressive multifocal leukoencephalopathy and apoptosis of infected oligodendrocytes in the central nervous system of patients with and without AIDS. Arch Neurol 59:1930-1936

109. Sabath BF, Major EO (2002) Traffic of JC virus from sites of initial infection to the brain: the path to progressive multifocal leukoencephalopathy. J Infect Dis 186(Suppl 2):S180-S186

110. Saffert RT, Kalejta RF (2008) Promyelocytic leukemia-nuclear body proteins: herpesvirus enemies, accomplices, or both? Future Virol 3:265-277

111. Salomoni P, Pandolfi PP (2002) The role of PML in tumor suppression. Cell 108:165-170
112. Saudou F, Finkbeiner S, Devys D, Greenberg ME (1998) Huntingtin acts in the nucleus to induce apoptosis but death does not correlate with the formation of intranuclear inclusions. Cell 95:55-66

113. Seth P, Diaz F, Major EO (2003) Advances in the biology of JC virus and induction of progressive multifocal leukoencephalopathy. J Neurovirol 9:236-246

114. Seth P, Diaz F, Tao-Cheng JH, Major EO (2004) JC virus induces nonapoptotic cell death of human central nervous system progenitor cell-derived astrocytes. J Virol 78:4884-4891

115. Shintaku M, Matsumoto R, Sawa H, Nagashima K (2000) Infection with JC virus and possible dysplastic ganglion-like transformation of the cerebral cortical neurons in a case of progressive multifocal leukoencephalopathy. J Neuropathol Exp Neurol 59:921-929

116. Shishido-Hara Y, Hara Y, Larson T, Yasui K, Nagashima K, Stoner GL (2000) Analysis of capsid formation of human polyomavirus JC (Tokyo-1 strain) by a eukaryotic expression system: splicing of late RNAs, translation and nuclear transport of major capsid protein VP1, and capsid assembly. J Virol 74:1840-1853

117. Shishido-Hara Y, Higuchi K, Ohara S, Duyckaerts C, Hauw JJ, Uchihara T (2008) Promyelocytic leukemia nuclear bodies provide a scaffold for human polyomavirus JC replication and are disrupted after development of viral inclusions in progressive multifocal leukoencephalopathy. J Neuropathol Exp Neurol 67:299-308

118. Shishido-Hara Y, Ichinose S, Higuchi K, Hara Y, Yasui K (2004) Major and minor capsid proteins of human polyomavirus JC cooperatively accumulate to nuclear domain 10 for assembly into virions. J Virol 78:9890-9903

119. Shishido Y, Nukuzuma S, Mukaigawa J, Morikawa S, Yasui K, Nagashima K (1997) Assembly of JC virus-like particles in COS7 cells. J Med Virol 51:265-272

120. Shitrit D, Lev N, Bar-Gil-Shitrit A, Kramer MR (2005) Progressive multifocal leukoencephalopathy in transplant recipients. Transpl Int 17:658-665

121. Silverman L, Rubinstein LJ (1965) Electron microscopic observations on a case of progressive multifocal leukoencephalopathy. Acta Neuropathol 5:215-224

122. Sisodia SS (1998) Nuclear inclusions in glutamine repeat disorders: are they pernicious, coincidental, or beneficial? Cell 95:1-4

123. Skinner PJ, Koshy BT, Cummings CJ et al (1997) Ataxin-1 with an expanded glutamine tract alters nuclear matrix-associated structures. Nature 389:971-974

124. Sock E, Renner K, Feist D, Leger H, Wegner M (1996) Functional comparison of PML-type and archetype strains of JC virus. J Virol 70:1512-1520

125. Sun Y, Durrin LK, Krontiris TG (2003) Specific interaction of PML bodies with the TP53 locus in Jurkat interphase nuclei. Genomics 82:250-252

126. Suzuki S, Sawa H, Komagome R et al (2001) Broad distribution of the JC virus receptor contrasts with a marked cellular restriction of virus replication. Virology 286:100-112

127. Sweeney BJ, Manji H, Miller RF, Harrison MJ, Gray F, Scaravilli $\mathrm{F}$ (1994) Cortical and subcortical JC virus infection: two unusual cases of AIDS associated progressive multifocal leukoencephalopathy. J Neurol Neurosurg Psychiatry 57:994-997

128. Takahashi J, Fujigasaki H, Iwabuchi K et al (2003) PML nuclear bodies and neuronal intranuclear inclusion in polyglutamine diseases. Neurobiol Dis 13:230-237

129. Takahashi J, Fujigasaki H, Zander C et al (2002) Two populations of neuronal intranuclear inclusions in SCA7 differ in size and promyelocytic leukaemia protein content. Brain 125:15341543 
130. Tan CS, Dezube BJ, Bhargava P et al (2009) Detection of JC virus DNA and proteins in the bone marrow of HIV-positive and HIV-negative patients: implications for viral latency and neurotropic transformation. J Infect Dis 199:881-888

131. Tavalai N, Stamminger T (2008) New insights into the role of the subnuclear structure ND10 for viral infection. Biochim Biophys Acta 1783:2207-2221

132. Terris B, Baldin V, Dubois S et al (1995) PML nuclear bodies are general targets for inflammation and cell proliferation. Cancer Res 55:1590-1597

133. Tornatore C, Berger JR, Houff SA et al (1992) Detection of JC virus DNA in peripheral lymphocytes from patients with and without progressive multifocal leukoencephalopathy. Ann Neurol 31:454-462

134. Trowbridge PW, Frisque RJ (1995) Identification of three new JC virus proteins generated by alternative splicing of the early viral mRNA. J Neurovirol 1:195-206

135. Van Assche G, Van Ranst M, Sciot R et al (2005) Progressive multifocal leukoencephalopathy after natalizumab therapy for Crohn's disease. N Engl J Med 353:362-368

136. Vendrely A, Bienvenu B, Gasnault J, Thiebault JB, Salmon D, Gray F (2005) Fulminant inflammatory leukoencephalopathy associated with HAART-induced immune restoration in AIDSrelated progressive multifocal leukoencephalopathy. Acta Neuropathol 109:449-455

137. Walker DL, Padgett BL, ZuRhein GM, Albert AE, Marsh RF (1973) Human papovavirus (JC): induction of brain tumors in hamsters. Science 181:674-676

138. Weggen S, Bayer TA, von Deimling A et al (2000) Low frequency of SV40, JC and BK polyomavirus sequences in human medulloblastomas, meningiomas and ependymomas. Brain Pathol 10:85-92

139. Wei G, Liu CK, Atwood WJ (2000) JC virus binds to primary human glial cells, tonsillar stromal cells, and B-lymphocytes, but not to T lymphocytes. J Neurovirol 6:127-136
140. Weidenheim KM, Nelson SJ, Kure K, Harris C, Biempica L, Dickson DW (1992) Unusual patterns of Histoplasma capsulatum meningitis and progressive multifocal leukoencephalopathy in a patient with the acquired immunodeficiency virus. Hum Pathol 23:581-586

141. White FA III, Ishaq M, Stoner GL, Frisque RJ (1992) JC virus DNA is present in many human brain samples from patients without progressive multifocal leukoencephalopathy. J Virol 66:5726-5734

142. White MK, Gordon J, Reiss K et al (2005) Human polyomaviruses and brain tumors. Brain Res Brain Res Rev 50:69-85

143. Wuthrich C, Cheng YM, Joseph JT et al (2009) Frequent infection of cerebellar granule cell neurons by polyomavirus JC in progressive multifocal leukoencephalopathy. J Neuropathol Exp Neurol 68:15-25

144. Wuthrich C, Dang X, Westmoreland S et al (2009) Fulminant JC virus encephalopathy with productive infection of cortical pyramidal neurons. Ann Neurol 65:742-748

145. Yang B, Prayson RA (2000) Expression of Bax, Bcl-2, and P53 in progressive multifocal leukoencephalopathy. Mod Pathol 13:1115-1120

146. Yogo Y, Kitamura T, Sugimoto C et al (1991) Sequence rearrangement in JC virus DNAs molecularly cloned from immunosuppressed renal transplant patients. J Virol 65:2422-2428

147. Yogo Y, Kitamura T, Sugimoto C et al (1990) Isolation of a possible archetypal JC virus DNA sequence from nonimmunocompromised individuals. J Virol 64:3139-3143

148. Yousry TA, Major EO, Ryschkewitsch C et al (2006) Evaluation of patients treated with natalizumab for progressive multifocal leukoencephalopathy. N Engl J Med 354:924-933

149. Zheng H, Abdel Aziz HO, Nakanishi Y et al (2007) Oncogenic role of JC virus in lung cancer. J Pathol 212:306-315

150. Zurhein G, Chou SM (1965) Particles resembling papova viruses in human cerebral demyelinating disease. Science 148:14771479 